\title{
Museums and Workers: Negotiating Industrial Heritage in the Former Yugoslavia
}

\section{Tanja Petrović}

Research Centre of the Slovenian Academy of Sciences and Art, Ljubljana, Slovenia

The article discusses tensions, ambiguities, and political implications of the fact that what is nowadays negotiated as industrial heritage is still part of the lived experience of several generations of men and women in the former Yugoslavia. It argues that the issues of representation of industrial labor essentially have to do with the place given to the working communities, their members as well as their voices and affects in the museum narratives.

Key words:

industrial heritage, workers, affect, experience, postsocialism

Twenty years after socialism and the Yugoslav state ceased to exist, one of the most powerful metaphors of the Yugoslav socialist lifeworld, collective industrial labor, ${ }^{1}$ experienced dramatic transformations. Ruination and abandonment of large industrial complexes, job loss, and a shift away from industrial production towards the service sector are, of course, not

${ }^{1}$ The issue of industrialization is particularly relevant in the area of the former Yugoslavia, for at least two reasons. Firstly, because industrialization and modernization in Yugoslavia were almost exclusively socialist projects. The modernization of the Yugoslav society was achieved through deagrarization and industrialization (cf. Marković 2002) and in this sense Yugoslavia differed from the socialist countries with an already established working class culture (for the case of Poland see Kenney 1994). Secondly, because the role of the worker in Yugoslavia was central for construing a cosmopolitan, internationalist, modern, and supranational identity of Yugoslavs in the socialist period - the identity that was strongly neglected by nationalist elites in post-Yugoslav societies. Ruins of the industrial era strongly connected with socialism evoke ruined potential for negotiation of identities that would offer an alternative to divisions along ethnic and religious lines that currently dominate the post-Yugoslav spaces. 
only symptoms of the post-socialist transition, but a global condition of the post-industrial era and "the transition from industrial manufacture to digital technologies" (Scribner 2003: 17; see also Blackmar 2001). This transition, followed by fragmentation and globalization of production processes, affected not only the ways people work and understand their labor, but also their emotions, affects and desires. ${ }^{2}$ Essentially a global phenomenon, the disappearance of collective industrial labor deserves particular attention in the case of post-socialist European societies. There, the transition from industrial to post-industrial society was paralleled by another transition - the one from socialism to democracy. It was characterized by murky privatizations of state-owned socialist factories and their subsequent destruction, and by severe deprivation of the citizens of post-socialist societies in general, and industrial workers as the most vulnerable social group in particular, of basic rights and of a means of proactive engagement with the present and the future of the societies in which they live. Representations of industrial labor in the collective memory of post-socialist Europe are essentially linked to the ways in which socialism is perceived as a European historical legacy. In the West the end of the industrial era is considered as a natural evolutionary step of Western capitalism, whereas such a naturalization view faces serious difficulties in the former socialist societies. This is even truer in the case of former Yugoslavia, where the socialist legacy inevitably evokes a supranational Yugoslav context.

In the transition from industrial to post-industrial, from socialist to post-socialist societies, the worker as an ideological figure and a symbol of the value of labor disappeared from public spaces, billboards and banknotes. As a constitutive element of the working class, the worker was moved from society's center to its margins, to suburbs, to the "third world". ${ }^{3}$ Workers became silent political subjects with no available means to articulate their demands. Workers were no longer part of the ideological realm, but only of the existential realm; hence, they were forced to fight for their basic existential rights. "Heroes of work" became "victims of

${ }^{2}$ Matthew Crawford (2009) provides an insightful reflection on these changes and their consequences.

${ }^{3}$ Today migrant workers in Slovenia who come from the other former Yugoslav republics are largely treated as people from "the third world" - and subjected to severe discrimination and human rights violations.

${ }^{4}$ Hunger strikes became the dominant form of this struggle. Deprived of all other instruments in their attempts to secure a bare existence for themselves and their families, workers often resort 
transition". This transformation, its causes and consequences occupy an important place in public debates and artistic reflections in post-Yugoslav societies. For example, a series of theatre plays deal with these issues: in April 2010, the Belgrade Atelje 212 theatre staged a play, Da nam živi, živi rad (Celebrate work), written by Milan Marković and Anđelka Nikolić and directed by Anđelka Nikolić. The authors use the form of an agitprop play to reconsider human labor and its role in the present "half-wild and half-organized system". According to the play's director, "this painfully topical play explores the phenomenon of labor in the present and tries to lead us along the painful path of Serbia's transition" ( $D a$ nam živi... 2010). In the Slovenian city of Maribor, which was European Capital of Culture in 2012, a documentary play Was ist Maribor was staged in the abandoned boiler house of the Maribor Automobile Factory (TAM). The play reveals problematic ways in which this once successful factory was led to bankruptcy. The text of the play Radnici umiru pevajući (Workers die singing), ${ }^{5}$ a brutal story about humiliation and physical deterioration of workers of a factory in Serbia written by Olga Dimitrijević, received the first Heartefact Fund award in 2010.

Despite the degrading and humiliating position of industry and industrial workers in the former Yugoslav societies, the memory of socialist industrial labor still has a lure, attraction and mobilizing potential. ${ }^{6}$ A number of cafes, restaurants, publishing houses, cultural organizations, and alternative spaces in the post-Yugoslav space which contain fabrika, tvornica or tovarna (factory) in their name confirm the high symbolic value this memory still possesses. This symbolic potential is even more widely employed in art $^{7}$

to radical means of protest and bodily interventions: a powerless working mother burned herself in the presence of her children, while a worker from Novi Pazar in Serbia cut and ate his finger (Gregorčič 2010). Marta Gregorčič reports on many other similar cases: "180 workers of the privatized construction enterprise ' 1 May' in Lapovo (Serbia) who had not received their salaries for 8 months, decided to commit collective suicide on June 10,2009. They lay down on the tracks at a local train station, on the Belgrade-Niš railroad, the one that they had built many years ago. 250 dismissed workers joined them. They also received support from more than 200 workers of the company Electro in Rača, who were in the 15th day of their hunger strike" (ibid.).

${ }^{5}$ The title refers to the TV series The Thorn Birds which was translated into Serbo-Croatian as Ptice umiru pevajući.

${ }^{6}$ Socialist factory work and solidarity on the factory floors were strong symbols for Western intellectuals during the Cold War as well. Charity Scribner discusses writings by novelists from the 1970s and 1980s which "eulogize not only the last hopes for a socialist alternative and a singular prospect for international solidarity, but also a particular vision of collective and collaborative work" (Scribner 2002: 237).

7 The exhibition A Series of monuments - unforgettable moments in the life of Novi Beograd 
and popular culture. For example, self-organized activist choirs that have emerged in several Yugoslav successor states during the last decade, ${ }^{8}$ give particular focus to the theme of work, workers, and their role in socialism. Songs of "work and construction" from the socialist period, when labor was promoted as a value shared by all and the worker was the central figure of socialist ideology, are an important part of their repertoire. In addition to referring to work in socialism in its repertoire and its very name, the female choir Kombinat from Ljubljana refers to work by making extensive use of socialist worker-related iconography on its website, posters announcing their performances, etc. The members of the Belgrade choir Horkestar (ex Horkeškart) often perform dressed in blue worker overalls; the (female) conductor wears borosane, a recognizable kind of shoes worn by women at their workplace during socialism (made by the Borovo shoe factory, hence the name). Songs about work and building the country are an important part of their repertoire; they often perform in places that used to be symbolically connected with the ideology of industrial work in socialism (mining towers, abandoned factories...). The Macedonian choir

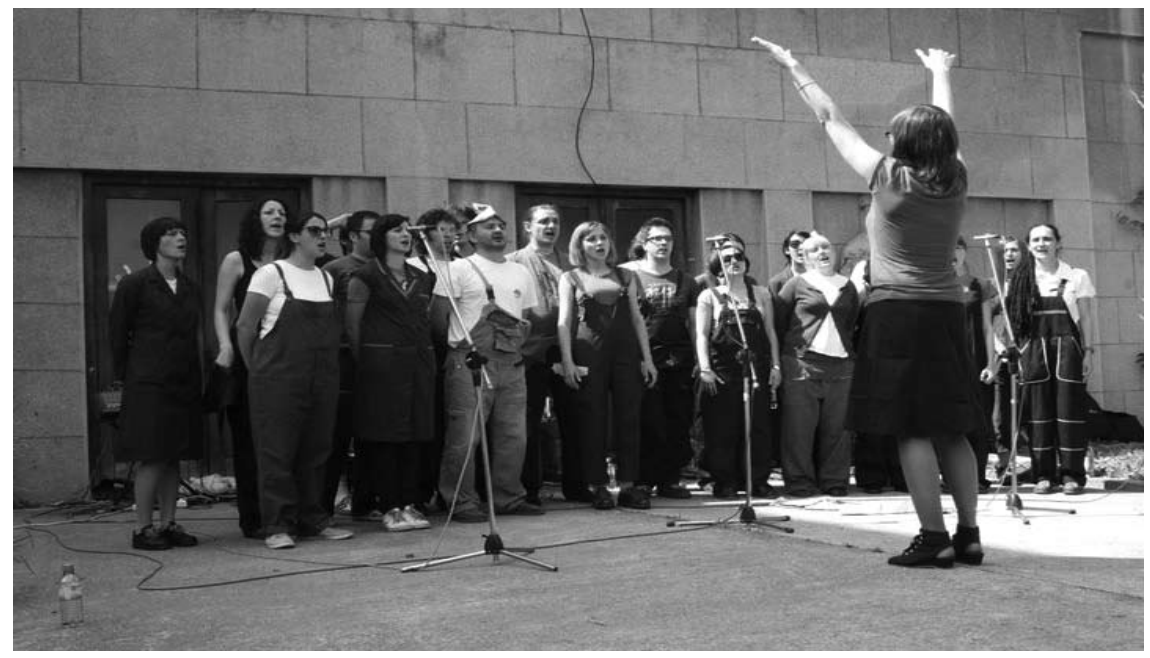

Figure 1. Horkestar's performance in Skopje, May 2010. Photo by Branka Nađ

workers - by Vladan Jeremić and Rena Rädle, which features photos of the two artists dressed in worker overalls, aims to ask the question "what happens with the newly formed working class around us" (Politika, 16 July 2008). In his projects Invisible Sisak and Levels and Targets, the Croatian artist Marijan Crtalić comments on the existence of socialist steelworks in the landscape of the town of Sisak during socialism and after it (Potkonjak and Pletenac 2011).

${ }^{8}$ For more on self-organized choirs, see Petrović 2011. 
Raspeani Skopjani, together with the civic initiative Ploštad Svoboda, sings the song Gradot ubav pak ke nikne (The beautiful city will spring up again) that was sung during the reconstruction of Skopje after the disastrous earthquake of 1963. In this way, its members protest against the plan of the city authorities to build a church on Skopje's main square. ${ }^{9}$

A growing interest for and fascination with socialist industrial labor history may be observed in yet another field: there is a significant number of attempts to frame this history as cultural heritage that offers a representation of socialist industrial work through institutionalized, museumized narratives. Several projects of museumizing former industrial sites have been launched recently. This increased interest for industrial heritage should also be seen in the context of a broader enterprise of constructing "European identity" through museum practices, which is a current trend. Industrial heritage has a prominent position within this enterprise: as stressed in a promotional booklet for the project of promoting industrial heritage in the Croatian capital of Zagreb, the importance of local industrial heritage lies in the fact that it "is a part of the common European identity (Europe is the 'cradle' of industry)" (Zagrebačka industrijska baština 2010).

This article focuses on the processes of negotiating the history of socialist industrial labor as cultural heritage. My aim is to capture that vital moment when very different negotiations and appropriations of symbolism of the socialist industrial labor coincide and compete with each other. Whereas heritage sites developed on the site of former industrial complexes and the heritage of the working class(es) in the West have already attracted significant attention of scholars and museum workers (see, among others, Barndt 2010; Debary 2004; Del Pozo and González 2012; Linkon and Russo 2002; Shackel 2009; Smith, Shackel and Campbell 2011), the emerging field of (post-)socialist industrial heritage industry remains undertheorized and absent from ongoing academic debates. ${ }^{10}$ One of the principal characteristics of the present historical moment when

\footnotetext{
${ }^{9}$ In spite of their alternative, artistic, and maybe somewhat elitist standpoint, it would be wrong to ascribe irony to the way in which these choirs exploit the symbolism of industrial labor. The refusal of irony in the case of post-socialist Hungary was described by Maya Nadkarni (2007).

${ }^{10}$ Intriguingly, the volume Heritage, Labour and Working Classes (Smith, Shackel and Campbell 2011) discusses the nature of the working class heritage in contributions "from a number of Western countries including the USA, UK, Spain, Sweden, Australia and New Zealand", but not a single contribution deals with post-socialist/Eastern European countries, and the editors do not problematize or justify in any way the absence of the post-socialist working class from the volume.
} 
these negotiations and appropriations of the socialist industrial heritage emerge is the fact that socialist industrial labor and the modernization of the former Yugoslav societies are being turned into heritage while they are still part of personal biographies and experiential memory for several generations of former Yugoslavs. Furthermore, the nature of postsocialist transition prevents places related to socialist industrial labor to be definitely and unambiguously positioned in the past, which makes industrial heritage negotiations even more contested, ambiguous and difficult to be articulated.

Having all this in mind, the issues of representation of industrial labor essentially have to do with the place dedicated to working communities, their members as well as their voices and affects in the museum narratives. ${ }^{11}$ This article asks questions such as: To which extent does this industrial heritage "in the making" that we are witnessing in the post-Yugoslav societies directly relate to industrial workers and may be a means of empowering former or current industrial workers? To which extent does it shape the everyday practices and ways of legitimization of communities in (post-) industrial towns across the former Yugoslavia? And finally, what do calls for solidarity (which are often articulated at the former industrial sites which are being turned into heritage or articulated through the reinterpretations of socialist labor history) mean for the people who have been creating and shaping (and were also shaped by) these sites and that history? Again, the relevance of these questions is not limited to the socialist industrial heritage, but also concerns Western industrial heritage-making. However, because of the mentioned absence of the former socialist societies from the global map of industrial heritage-making, it is very important to ask these questions in the post-socialist context. The position in which (former) industrial workers found themselves in the process of "post-socialist transition", makes this an even more important issue: as Smith, Shackel and Campbell (2011: 1) emphasize, "for all those who hold an interest in forms of heritage [...], there is a moral imperative to address the issues of class and economic and social inequality" (Sayer 2005) and "its hidden injuries to self-respect and self-worth" (Cobb and Sennett 1973).

The ambiguous relationship between the conceptualization of industrial heritage and the people who were the actors of industrialization has been

${ }^{11}$ The relationship between museums and communities has been in the focus of attention of several academic works for some time already: see Crooke 2007; Karp, Mullen Kreamer and Lavine 1992; Karp et al. 2006; Watson 2007. 
noted on a global scale. Smith, Shackel and Campbell stress that "the people, communities, events, and places that constitute working class heritage are underrepresented in national and international heritage efforts" (Smith, Shackel and Campbell 2011; cf. Del Pozo and González 2012). Despite the fact that exhibiting/museumizing the industrial past presupposes and requires a distinct locality - these practices are always located in and intrinsically connected with not only the (former) industrial landscape, but also with the specific communities formed around the industrial sites and significantly defined by them - the relationship between museum narratives and the corresponding communities seems difficult to establish. It is part of a broader representational problem that, in addition to museum exhibitions, also affects other narratives about industrial labor: as noticed by Andrea Matošević in his study of the mining culture in the Labin area in Istria (2011: 13, 30), historiographical and documentary narratives tell the story of the industrialization of the former Yugoslavia without letting its main actors - the workers - talk for themselves. The discussed popular culture endeavors face the same problem.

Within the expanding realm of industrial heritage sites, practices and narratives in the former Yugoslav societies, four general trends in museumizing the history and memory of socialist industrial labor are evident: a) the linearization of the particular generational experience of industrial labor, its incorporation into broader and more general historical flows; b) the commercialization of experience of industrial labor; c) a normative approach to industrialization and modernization and their outcomes in the former Yugoslavia and d) a nationalization of the Yugoslav labor history in Yugoslav successor states.

\section{LINEARIZATION}

"Museumization" of the Yugoslav experience always, at least to some extent, implies its transformation into a linear historical narrative and thereby its "pacification" and emotional discharge. Museum exhibitions also always position the distinct, generational experience of socialist industrial modernization of the members of a particular community into a much broader historical context. For instance, in the case of steel and iron industry, museum narratives usually start with prehistory. In the narratives of industrial heritage, it is almost never socialist industrial labor and the 
particular generational experience of it that is stressed and elaborated. In the Coal Mining Museum of Slovenia in Velenje, for example, much more attention is paid to older periods of mining history - the 18th and 19th century, and the early 20 th century. Its website invites visitors to "experience how miners lived more than 100 years ago" (Muzej premogovništva Slovenije). A similarly temporalized museum narrative also appears in the Museum of Jesenice, an industrial town in northern Slovenia, where strong emphasis is given to pre-WW2 steel industry (Workers' living culture).

To become part of a museum narrative, the industrial past has to unambiguously and irreversibly belong to the past. It must be perceived "as an unexceptional consequence of the end of history" (Blackmar 2001: 338) and as a symptom "of the absolute pastness of the past" (Janowitz 1990, cf. Edensor 2005: 13). One needs to bear in mind, however, that many big projects of socialist industrialization are spaces where "transition/ transformation" never actually began and where people are still "waiting for capitalism to come". Industrial ruins in former large industrial centers are in many cases not abandoned as elsewhere in the world, but still populated by workers who have continued to come to work every day, repeatedly facing gradual decay and impoverishment, since many giant factories were too large and had too many employees to be easily or completely privatized (for the case of the Jagodina Cable Factory in Serbia, see Petrović 2010). ${ }^{12}$ Industrial ruins cannot be transformed into memory, since for many people they are still part of reality and their everyday struggle. They stress "the experience of loss as ongoing, touching the present" (Barndt 2010: 287). Moreover, in those cases when big socialist industrial companies were destroyed and their buildings abandoned, these abandoned ruins do not completely belong to the past, since no new reality with new possibilities has replaced the world of socialist industrial work. For example, in the small industrial town of Breza in Bosnia and Herzegovina, the old spinning factory has been abandoned along with the other factories, and the mine operates at reduced capacity, but for most of the population no new possibilities of employment appeared with the transformation and industrial decline. All these former industrial areas still live in the present which is, in fact, an extended past, with no opportunity of making an essential step forward

12 In 2011, the Serbian media reported on the government program to support foreign investments in Serbian towns which were former industrial centers by subsidizing job creation. According to Nebojša Ćirić, the Minister of Regional Development, the government hopes to "revive big industrial centers inhabited by $20 \%$ of the population of Serbia" in this way ("Vlada oživljava industrijske centre" 2011). 
that would enable distancing the present from the industrial past, reflecting upon it and eventually turning it into legacy/heritage. They are spaces of contestation and unrest, which strongly resist pacification that linear, historicized museum presentations impose on them.

\section{COMMERCIALIZATION}

Turning ruined, abandoned or half-ruined and half-abandoned industrial sites and areas into a tourist attraction is a general trait in industrial heritage making, which is being realized by means of a close connection to the tourism industry. Making tourist attractions out of industrial ruins is seen as a way out of economic decay and deprivation. As a rule, this process does not concern itself with memories, experiences and sensibilities of the (former) workers and local community members: as argued by Del Pozo and González (2012: 446-447), "industrial heritage has [...] been largely utilized as a future-oriented economic resource, neglecting emotional and popular potential for the generation of new identities and connections with the past".

The Coal Mining Museum of Slovenia in Velenje is advertised as a place that offers visitors "a unique mining experience: they can take a ride on the underground train, have a genuine miners' meal and experience the smell of wood and coal" ("Muzej premagovništva Slovenije - predstavitev"). The museum website emphasizes that it is the museum's "ambition [...] to bring the story of Slovenian coal mining closer to as many visitors as possible, regardless of age, physical ability, linguistic competence or other factors".

In the process of linearization described above, the distinctive generational experience is being reduced to objects-as-monuments and thus "pacified", purged of affect and included into a linear historical narrative. In contrast, the commercialization of working experience in the process of industrial heritage making always involves its dehistorization: it is no longer a distinct generational experience, but a dehistoricized, deterritorialized and decontextualized set of images, practices and perceptual stimuli promising a "first-hand experience" to the visitors. The two processes, although seemingly opposed, are in fact complementary to each other, since both result in the same effect: they widen the gap between museum narratives and local communities. The Coal Mining Museum of Slovenia is located in Velenje, a coal mining and industrial town in Central 
Slovenia that was established as an urban settlement during socialism and inhabited by workers from all parts of the former Yugoslavia. In the post-socialist, independent Slovenia, Velenje preserved its distinctive, multicultural character and its image of a worker town. The exhibitions of the Coal Mining Museum of Slovenia, however, do not include much of the experience, memories and voices of the mining community members. When I saw the museum in May 2012, there was a temporary exhibition of painted portraits of miners, which was the only direct reference to the real, still-living people - the community members that used to work in the mining industry. The overall museum narrative is centered on the history of coal mining in Velenje and the history of the mines, and is organized either chronologically or around mining-related objects (the exhibition of miner's lamps, a reconstruction of "white" and "black" wardrobes, a reconstruction of miners' homes from the early $20^{\text {th }}$ century).

This historicized, linearized narrative is complemented by the "tourist attraction" approach which offers a "first-hand experience": visitors receive helmets and tokens with numbers at the beginning of the tour, they go down to the mines, they can eat in the miner's canteen etc. The museum also hosts a wide range of elitist cultural and social events, such as fashion shows and underground concerts, which may foster local economy and enliven local cultural life, but do not have much to do with the miners and their labor history.

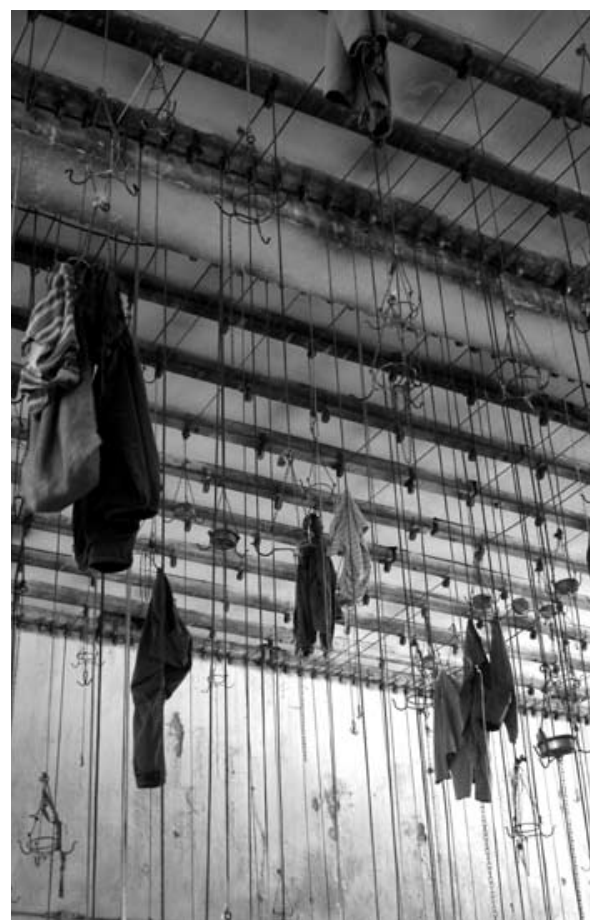

Figure 2. "Black wardrobe", the Coal Mining Museum of Slovenia, Velenje. Author's photograph 


\section{NORMATIVIZATION}

When the industrial socialist past is displayed in museums, exhibition authors typically take a normative, assessing stance toward the exhibited subjects and material and insist on a critical reading of that past. The majority of heritage practices that address the socialist industrial heritage in the former Yugoslavia are characterized by a detached approach that aims not to evoke, accommodate or transmit affect, but to provide an "objective" or "critical" assessment and description of phenomena belonging to the socialist past. Such an approach stems from the presumption that the socialist propaganda was too uncritical in stressing the positive aspects of industrialization and modernization so that a critical, detached, emotionally disinterested look back at their history is required to avoid yet another adulation.

In 2009 the Architecture Museum of Ljubljana organized the exhibition Iskra: Non-Aligned Design 1946-1990 dedicated to the products of Iskra, the largest electronics company in the former Yugoslavia, and in particular to their design and the design process used in the company. The evaluation of Iskra's achievements, the quality of its industrial design and the aesthetic value of its products were central to the discourse formed around this exhibition.

The insistence on an objective, non-emotional approach in interpreting the industrial legacy of Yugoslav socialism through museum exhibitions by no means implies that these exhibitions and their authors do not "count" on affective encounters of the visitors with the displayed artifacts. In fact, affect is quite frequently the mobilizing force that enables the creation of such exhibitions in the first place: the authors of the Iskra exhibition mention the delight and dedication with which the owners of old Iskra products (most of them former Iskra employees) contributed to the exhibition. A look at these products (telephones, TV and radio sets, kitchen appliances) clearly provokes a fair amount of emotions, particularly when those who produced or used them are concerned. This affect, however, is not capable of leaving the nostalgic register; the subjects who were the actors of industrialization were not portrayed as legitimate agents in the narratives of industrial heritage, nor can they use the meanings they attach to their own socialist past to articulate universal narratives and to negotiate their current positions and proactively approach them. 
Tanja Petrović, Museums and Workers: Negotiating Industrial Heritage in the Former Yugoslavia. Nar. umjet. 50/1, pp. 96-120

The affect provoked by the memories of industrial labor and its role in the formation of subjectivity of (former) industrial workers inevitably invokes debates about post-socialist nostalgia and Yugo-nostalgia as its specific manifestation in the former Yugoslav societies. ${ }^{13}$ Post-socialist subjects are widely delegitimized for their nostalgic feelings for the socialist past. This is even truer in the case of former socialist industrial workers: their memory practices that stress the positive aspects of socialism are derogatorily marked as post-socialist nostalgia and almost entirely interpreted as a strategy related to the present situation of workers and the difficulties they have in "getting by in post-socialism". For example, David Kideckel stresses that "nostalgia for socialism focuses on security - of one's job, of the community, of physical life". For him, "such selective use of the socialist model is ultimately futile and frustrating for effective agency, as it elevates relations and conditions that are thoroughly discredited today. Collectivist practices make little sense in post-socialist institutional contexts and have little support among either globalizing elites or the hard-pressed, but energetic, middle classes" (Kideckel 2008: 13). It is important to realize that such a negative attitude towards the workers' affect is not an exclusively post-socialist phenomenon, but part of a broader framework of post-industrial critique of the working class who "cherishes the romantic memory of a time when the working class could more easily produce its own meaningful world-view: the unproblematic community of the 'general interest'” (Wright 1985: 22). ${ }^{14}$

${ }^{13}$ For the broader post-socialist context, see Ghodsee 2011; Todorova and Gille 2010; for meanings and political implications of Yugo-nostalgia, see Palmberger 2008; Petrović 2012; Velikonja 2009a, 2009b.

${ }^{14}$ Such interpretation of workers' affective engagement with their own past has already been extensively criticized: for Western/post-Fordist contexts, see Blackmar 2001, as well as Smith (2006: 195), who argues that "nostalgia is often misidentified as being simply expressive of the ethos 'it was better back then', and fails to understand that nostalgic recollections can also involve critical and mindful memory work that recognizes and engages with the emotionally painful". As Robertson (cf. Smith, Shackel and Campbell 2011:3) argues, "discourses of 'nostalgia' and 'heritage industry' work to not only de-legitimise what he terms 'heritage from below,' but also to obscure its inherently dissonant nature and the links it maintains to social protest." In the case of the former Yugoslavia, I argued that the workers' insistence on values, relations and conditions that existed in socialism is more than a way to negotiate a better individual treatment and greater assistance from the society and is also more than mere "pining for a social safety net that never really existed" (Scribner 2003: 11). These narratives and practices (usually discredited as nostalgia for socialism) transcend individual and purely existential expectations and should be observed in a broader societal context: memories of work in socialism also provide a narrative of modernization that includes former socialist societies in the cultural and historical map of Europe (Petrović 2012). 


\section{NATIONALIZATION}

In 2010 the Slovenian Ethnographic Museum prepared an exhibition of "Slovenian brands" entitled Cockta - the drink of your youth and ours. The exhibition was an attempt to present Slovenian brands and to incorporate them into "the national identity held in museums" (Rogelj Škafar 2010: 7), as well as to stress the "importance that improving our knowledge about brands has for the national culture" (ibid.). The central part of the exhibition and the catalogue were dedicated to Cockta, a non-alcoholic beverage produced in the 1950 s as an alternative to Coca Cola. Cockta almost disappeared from the Yugoslav market when it opened to foreign products, but experienced two major "revivals", in the 1970s and in the 2000s. The fact that it is a successful product, one of the rare ones that managed to survive post-socialist transformations and marketglobalization, significantly shapes the ways in which it is presented. Although the history of Cockta is essentially determined by the Yugoslav socialist period, it is approached here from a purely profit- and market-oriented perspective, in which the rest of the former Yugoslavia is simply referred to as "new markets in the south".

Similarly to the Cockta exhibition, the museumization of industrial labor in the Yugoslav successor states often aims at strengthening national identity by framing industrial heritage as national heritage. This framing, however, encounters numerous difficulties and is faced with discomfort, coming not only from the fact that this heritage was importantly shaped by the Yugoslav socialist context, but also from the essentially supra-ethnic and multiethnic nature of the ways industry was organized, managed and interconnected in socialist Yugoslavia. ${ }^{15}$ Furthermore, memories of socialist labor and affect triggered by them cannot be positioned into nationally framed narratives of the post-Yugoslav national societies.

${ }^{15}$ The industrialization of Yugoslavia and the establishment of large factories caused a large scale migration not only from rural to urban areas, but also from one Yugoslav republic to another. Factories with interrelated production used to cooperate closely, and were sometimes even formally organized on the Yugoslav level: for example, steelwork plants were part of a Union of Yugoslav Steelworks - see Oder 2012: 22. Quite often, production itself was organized on the whole territory of Yugoslavia: for example, Cockta was produced or bottled in several places in all Yugoslav republics (Ramovš 2010: 72). 


\section{MUSEUMS IN RUINS}

All the described mechanisms contribute to a detachment of industrial heritage from the working communities, their members' experience, memories and sensibilities in most museum exhibitions in the former Yugoslavia. Dealing with the museumization of the industrial town of Sesto in Italy, Andrea Muehlebach (2011) asked the question whether a museum of solidarity is possible at all. Solidarity as the foundational value of industrial labor is often invoked in meta-discourses of industrial heritage making. Thus, The Coal Mining Museum of Slovenia in Velenje appears on the list of ten most attractive museums in Slovenia, which was published in the Saturday cultural supplement of the Slovenian daily Dnevnik dated 26 May 2012. According to the author of the list, the museum offers insight into miners' life and is also a good place "to remember miners' values such as solidarity, comradeship and mutual assistance" which have recently been gaining in importance (Brejc 2012: 27). The museum website stresses that 'the museum keeps old miners' values - comradeship, solidarity and assistance, which is also reflected in the attitude toward visitors and business partners" ("Poslanstvo muzeja").

Exhibitions and collections as well as practices related to them may accommodate the workers' affect - which would be a precondition for invoking solidarity - when they are located within working or local communities. Such exhibitions are intrinsically connected to industrial ruins: they can be found in the middle or on the edges of ruins and their meaning is created in dialogue with the ruins. ${ }^{16}$ The hall of the central administrative building of the Cable Factory in Jagodina (Serbia) houses a small exhibition which was set up in socialist times, and is still carefully maintained, even though the factory has already been in a state of decay and disintegration for more than twenty years. The exhibition displays the factory's products, photographs of workers in the production process, and of Tito and his guests from world politics visiting the factory.

While this small factory exhibition today "communicates" with the workers still employed at the factory and provides legitimacy for their largely questioned social role, a memorial room arranged at a public swimming pool in the small industrial and mining town of Breza in

${ }^{16}$ Ruins, and industrial ruins in particular, and their relationship to modernity, increasingly attract interest among researchers: see, among others, Blackmar 2001; Edensor 2005; Hell and Schönle 2010; Schönle 2012. 


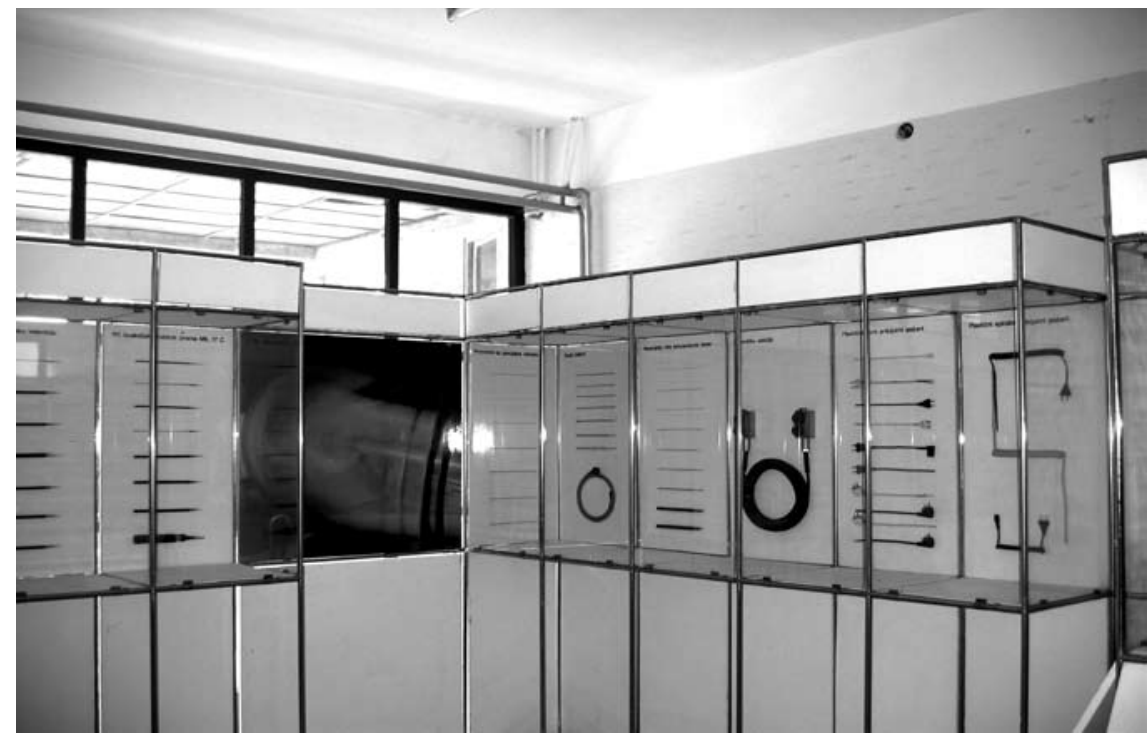

Figure 3. Exhibition room, the Cable Factory in Jagodina, Serbia. Author's photograph

Bosnia and Herzegovina has a slightly broader audience that encompasses the whole local community. It exhibits miners' "accessories" such as lamps and helmets and a series of photographs, most of which show Breza's most famous miner - Alija Sirotanović, a "Hero of Socialist Work".

Finally, when considering practices of "museumization" of the industrial past that are characterized by affect, one should not forget activities that remain in the realm of the personal and the private, such as collecting practices, private collections and personal archives. Many individuals devotedly collect, keep, preserve and exchange objects from destroyed factories and former industrial sites. The interest in such objects does not reflect the "usual" collectors' passion for the old. The affect that accompanies these collecting practices is of a different kind: it is related to personal engagement with the objects from one's own past. In Jesenice, an industrial town in northern Slovenia, where the remnants of socialist industrialization are largely excluded from the "official" narrative of industrial heritage, there are individuals who collect objects related to the Jesenice ironworks, which was destroyed fifteen years ago. In this way, collectors - many of them former employees - attach cultural value to the individual and collective past that the authoritative institutions have not acknowledged as worthy of remembering.

These practices allow for affect of community members to be accommodated in places and narratives that negotiate industrial past 
as cultural heritage. However, these remain outside more comprehensive mechanisms and policies regulating the heritage industry. Remaining limited to the working or local community, these practices cannot provide a means of empowerment of the community members or provide them with a sense of agency, nor can they offer a means to establish continuity between the socialist past and the post-socialist present.

In the former industrial areas of the former Yugoslavia, particularly those most severely affected by deindustrialization, there have been attempts by artists and activists to negotiate the local industrial history as cultural heritage and openly communicate with the dominant,

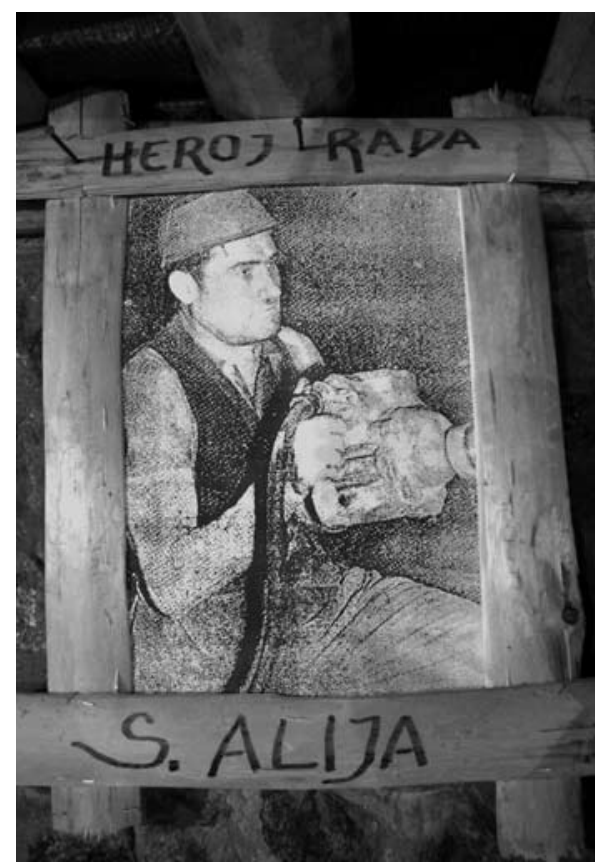

Figure 4. Memorial room in Breza, Bosnia and Herzegovina. Author's photograph institutional heritage discourses. Activities of amateur photographers of the Hrastnik Photo Club in Zasavje, Slovenia is one of these artistic/activist, locally anchored practices of negotiation of industrial cultural heritage. Zasavje was a traditionally industrial and mining area which was devastated by deindustrialization and is now one of the poorest regions in Slovenia with limited prospects for growth. The Hrastnik Photo Club organized four exhibitions entitled Industrial Heritage of Zasavje 2006 - 2010. At the opening of the last exhibition in November 2010 there was a reading of the "Official Statement of the Office for the Protection of Proletarians and Comradeship", which said that the "proletariat and comradeship are on the verge of extinction". The fictitious office of the Slovenian government was credited with saying that it "has the responsibility to draw public attention to Zasavje's cultural heritage, which is of global importance" and stressing that "the state is obliged to take care of its cultural heritage, and in this case,the industrial heritage of Zasavje, the proletariat and its comradeship". ${ }^{17}$ This statement places the memory of industrial work in the context of universal

${ }^{17}$ The opening of the exhibition was recorded and is available at http://www.youtube.com/ watch?v=7fSzvrq58Pc (accessed 11 November 2011). 
values such as solidarity, comradeship and social responsibility, thus lending legitimacy to the local history of industrialization. The appropriation and subversion of the dominant discourse of national cultural heritage is a tool which can be used to effectively articulate a critique of the hegemonic and authoritative concept of cultural heritage. The political message intertwines with strong emotions evoked by the photographs of the ruined industrial sites of Zasavje. Moreover, the exhibition was organized in a space directly linked to the local industrial past: the Workers' Cultural Center (Slovenian: Delavski dom; Serbo-Croatian: Radnički dom); it was attended by former workers and miners and accompanied by the sounds of traditional miners' songs performed by a local group of singers.

The Working Collective is the title of the first publication that emerged in the framework of the project Bor - sometimes and always (Bore - ponekad $i$ stalno) carried out by the Regional Department (Zavičajno odeljenje) of the Municipal Library in Bor, an industrial town in eastern Serbia which has been heavily devastated in the process of deindustrialization, transition and privatization. The authors of this special publication are two artists and activists, Rena Rädle and Vladimir Jeremić. The authors' artistic reinterpretation of archival photographic and documentary material aims "to point to the central place of working culture in Bor, and to initiate solidarity and critical thinking and offer an alternative by rethinking and a reactualization of the workers' heritage" (Jeremić and Rädle 2012: 15). In November 2012, the Artistic Collective OUR (the name comes from the acronym for the Organization of Associated Labor, which was a legal unit in socialism) commemorated the $60^{\text {th }}$ anniversary of Jugoplastika in Split with posters displayed in the public transport buses and postcards sent to the addresses of ministries, educational and cultural institutions, containing the question “What is Split's heritage?" ("Jugoplastika 23. 11. 1952. - 23. 11. 2012.").

These kinds of reactualization place strong emphasis on the local histories of industrialization and the working culture of distinct, local working communities, insisting on their heritage value. However, even in these cases, the relationship between those represented and those who represent poses several questions and shares the mentioned concerns related to the absence of workers' voices in the representation of working cultures: they remain silent and unable to use their own heritage in a proactive way that would enable connecting the past with the present through everyday interactions and legitimizations of that heritage.

Narratives of socialist industrial heritage can become a means of 
empowerment, proactive engagement and a basis for solidarity (features that havebeen frequently mentioned in the described attempts to reactualize the history of socialist industrialization in the former Yugoslavia) only if workers themselves enter museum spaces and find a way not only to legitimize their past, but also to make sense of their present and their everyday through the heritage making process. One case of industrial heritage negotiation that manages both to provide a space to incorporate affective employment of one's own experience from the past, as well as to ensure a certain degree of agency and a sense of continuity and belonging for working community members is the permanent exhibition IMV-Wheels of Progress near Novo Mesto in Slovenia.

\section{WHEELS OF PROGRESS}

One early autumn morning in 2012, a colleague and I went to visit a museum exhibition of cars produced by IMV (Industry of Motor Vehicles) in Novo Mesto. ${ }^{18}$ Located in a former military storage facility in a wooded area of Dragančevje, this exhibition was not easy to find. When we finally managed to get to the fenced entrance, we were greeted by a note saying that the exhibition can be visited only by appointment and only on certain days of the week, and the day we came was not one of those. But after a few phone calls and some waiting, a man in his sixties came and let us in. This former worker of IMV, now in charge of the exhibition, was our host for the next two hours. He told us many stories about the factory and about this small museum, run by the Society of Friends of IMV. The Society's membership consists of former IMV employees, who are retired. "All kinds of people are members of the Society. Former directors, designers, technologists, technicians, workers... I had worked for IMV since 1968 and spent 40 years in this factory", said our guide.

While we were looking at the personal and delivery vehicles, caravans, and motor homes made by IMV and its successor companies that were on display, two other elderly gentlemen came in. They were the President and

${ }^{18}$ IMV was established in 1954 as Motomontaža, and renamed to IMV in 1959. The factory assembled cars by license for DKW, Austin and Renault, and designed and produced its own delivery vehicles, touring caravans, and motor homes. Since 1988 IMV is owned by Renault. The socialist IMV was succeeded by Revoz, Adria Mobil, TPV and several small companies in Slovenia and abroad (see Kočevar n.d. and "Zgodovina. Revoz"). 
the Treasurer of the Society. These energetic seniors discussed Society's operational matters and current issues. After a short but very friendly conversation with us, they left saying that there were many things to deal with, and hurried back to the Society office in the town.

These dedicated and busy pensioners managed to collect, restore and display a rich collection of cars produced by the IMV. The collection encompasses cars made in socialist Yugoslavia, as well as those made when IMV was transformed into Revoz, which produces Renault vehicles today. Making this exhibition required a tremendous amount of work, resources and engagement. The former IMV workers mobilized numerous institutions and organizations in Novo Mesto for their project: the municipality gave them a former military property for free to display and store the cars; the local paint factory donated cans of paint, students and teachers of the local technical high school repaired and repainted the old cars, and several local manufacturers helped with the car restoration free of charge. The Society was also able to intervene in the local memory landscape: on the Society's initiative, one of Novo Mesto streets was named after Jurij Levičnik, who was the Managing Director of IMV in the socialist era. His bust is located near the former IMV grounds. Moreover, the Society managed to penetrate the dominant institutionalized flows of heritage in Slovenia: The IMV exhibition was included into a series of six museum exhibitions within the Wow, industry! project, which was part of the program of Maribor 2012 - The European Capital of Culture (Wow, industry! 2012). Wheels of Progress is the only amateur exhibition not organized by an official heritage institution in this series.

The exhibition does not only provide a place for former workers' affective and engaged memories of participating in the socialist industrial project. It also gives them the possibility to actively engage in the preservation of the legacy of that project and to create the labor history of Novo Mesto by themselves. This engagement in the post-socialist present, in which, as it was noted in the outline of Wow, industry!, "global economic trends have almost obliterated industrial manufacturing in Slovenia" (ibid.), enables former workers to establish much needed continuity with the agency they possessed during socialism as workers and participants in industrialization and modernization.

Visually, the exhibition Wheels of Progress is centered upon a collection of vehicles produced by IMV and its three successor companies (Revoz, Adria Mobil and TPV). For each vehicle information is provided on its technical characteristics, its year of production, and the way in which it became part 
of the collection. The history of the factory and biographies of people who were instrumental in shaping it are described on posters. These are not "ordinary workers", but managers and members of the establishment at the time.

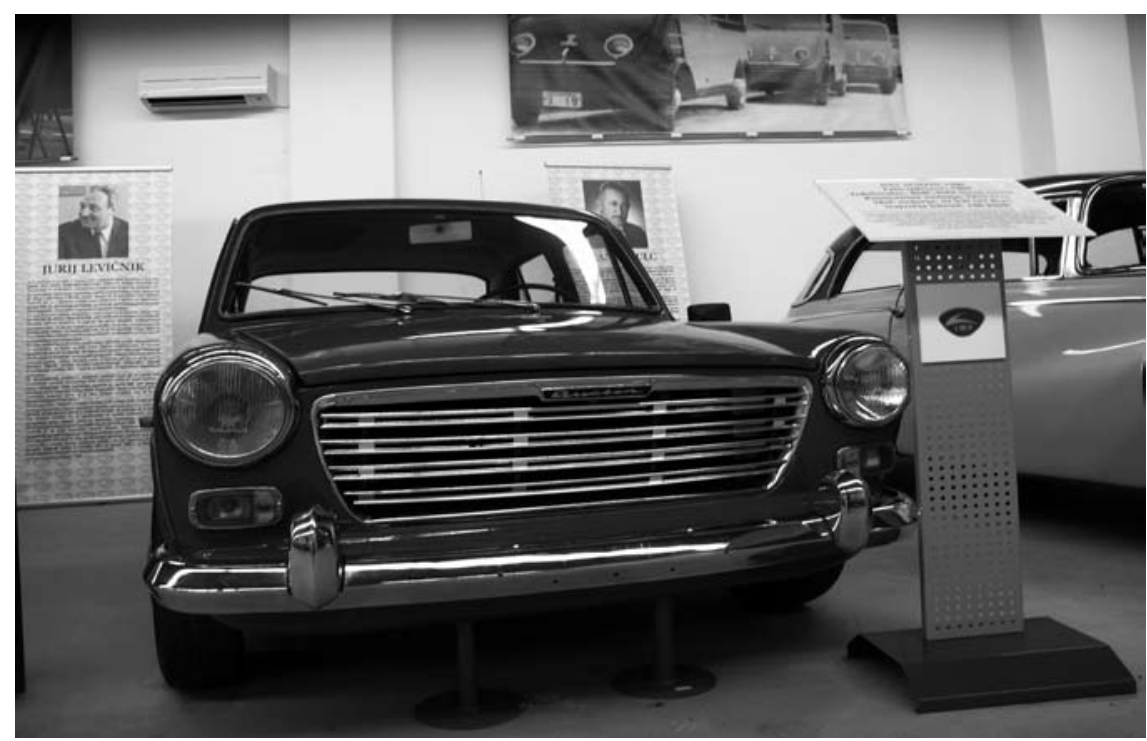

Figure 5: Wheels of Progress exhibition, Novo Mesto, Slovenia. Author's photograph

One room contains documents, technical instructions, models of cars, and promotional material from the socialist era, all displayed in showcases. The exhibition is thus presented in the conventional manner, with a "stress (on) physical fabric and technology" (Smith, Shackel and Campbell 2011), so that the displaying strategies alone do not suggest an exceptional status of this museum. It does not break the mold set by institutional, hegemonic, topdown oriented practices of industrial heritage making, at least not at first glance. Our guide explained that the Society is in the process of negotiation with the Technical Museum of Slovenia to include their collection of cars into the museum's permanent exhibition. "In this way, we will make sure that the collection lives longer then we do", he said. On the other hand, he stressed the important differences in the approach they have towards the collected artifacts: "Those museum people, they fill vehicle shells with concrete, so once cars enter the museum, they are no longer cars, but mere objects. They will be driven never again. Here, we keep our cars alive. You see this one? I drove it yesterday" - he said pointing to an old fire truck 


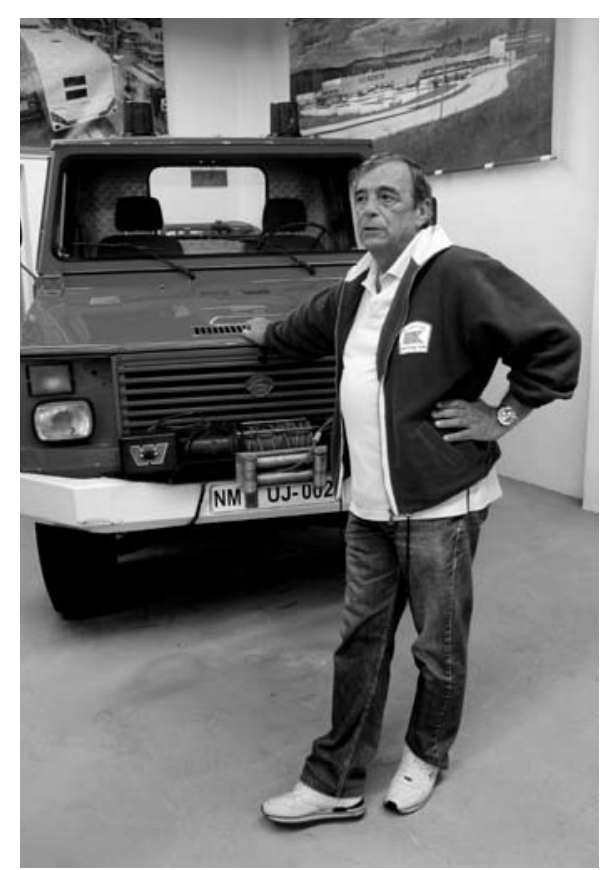

Figure 6: Exhibition guide, Wheels of Progress, Novo Mesto, Slovenia. Author's photograph produced by IMV. What additionally makes this exhibition exceptional are the history of its creation and the ways in which the displayed artifacts are related to the experience of the community members, their memories, their affective attachments to the production process in which they participated, as well as with their present everyday.

Wheels of Progress as a heritage practice provides a possibility for the former IMV workers to organize, socialize, and actively shape the public narrative of their labor past, but even more importantly, it enables them to negotiate the social relations and values that essentially defined their working community in the past as relevant, important and transposable to the present. When situated within local or workers' communities and shaped by the members of these communities, negotiations of socialist industrial heritage are capable of opening a space for questions of mutuality, solidarity and communal values. As such, they offer interpretative agency to citizens - former socialist workers - and tools to negotiate their legitimacy. Thus, if one is looking for solidarity in the industrial museums of the former Yugoslavia, Dragančevje near Novo Mesto is the place to go.

\section{Acknowledgements:}

I would like to thank Heidi Grunebaum, Jill Massino, Gavin Smith, Ciraj Rasool, Birgit Meyer, Paul Mepschen, and two anonymous reviewers for their thoughtful comments on earlier drafts of this article. Deana Jovanović, Tanja Radež, Maja Lovrenović, Nevena Paunović and Primož Tanko provided me with valuable information about practices of industrial heritage negotiation in different parts of the former Yugoslavia. 


\section{REFERENCES AND SOURCES}

Barndt, Kerstin. 2010. "Memory Traces of an Abandoned Set of Futures: Industrial Ruins in the Postindustrial Landscape in Germany". In Ruins of Modernity. Julia Hell and Andreas Schönle, eds. Durham and London: Duke University Press, 270-293.

Blackmar, Elisabeth. 2001. "Modernist Ruins”. American Quarterly 53/2: 324-339.

Brejc, Irena. 2012. "Deset najbolj privlačnih muzejev”. Dnevnik, Objektiv 26 May: 26-27.

Cobb, Jonathon and Richard Sennett. 1973. The Hidden Injuries of Class. New York: W. W. Norton \& Company.

Crawford, Matthew. 2009. Shop Class as Soulcraft: An Inquiry into the Value of Work. London: Penguin Books.

Crooke, Elisabeth. 2007. Museums and Community: Ideas, Issues and Challenges. New York: Routledge.

Da nam živi, živi rad. 2010. Pozorište Atelje 212. At http://www.atelje212.rs/teatar-upodrumu/da-nam-zivi-zivi-rad-m-markovic-a-nikolic (accessed 7 January 2011).

Debary, Octave. 2004. "Deindustrialisation and museumification: From exhibited memory to forgotten history". Annals of the American Academy of Political and Social Science 595/1: 122-133.

Del Pozo, Benito and Pablo Alonso González. 2012. "Industrial Heritage and place identity in Spain: From Monuments to Landscapes". The Geographical Review 102/4: 446-464.

Edensor, Tim. 2005. Industrial Ruins: Spaces, Aesthetics and Materiality. Oxford and New York: Berg.

Ghodsee, Kristen. 2011. Lost in Transition. Ethnographies of Everyday Life after Communism. Durham and London: Duke University Press.

Gregorčič, Marta. 2010. "Kako bodo delavci iz podjetja Prvi maj praznovali praznik delavstva?" Dnevnik, April 30.

Hell, Julia and Andreas Schönle. 2010. Ruins of Modernity. Durham and London: Duke University Press.

Janowitz, Anne. 1990. England's Ruins: Poetic Purpose and the National Landscape. Oxford: Blackwell.

Jeremić, Vladimir and Rena Rädle. 2013. Radnički kolektiv 1, December 2012.

Karp, Ivan, Christine Mullen Kreamer and Steven Lavine, eds. 1992. Museums and Communities: The Politics of Public Culture. Washington DC: Smithsonian Institution Press.

“Jugoplastika 23.11.1952. - 23.11.2012." At http://pogledaj.to/drugestvari/jugoplastika23-11-1952-23-11-2012/ (accessed 31 January 2013).

Karp, Ivan, et al., eds. 2006. Museum Frictions: Public Cultures / Global Transformations. Durham: Duke University Press.

Kenney, Padriac. 1994. "Remaking the Polish Working Class: Early Stalinist Models of Labor and Leisure". Slavic Review 53/1: 1-25. 
Kideckel, David. 2008. Getting by in Post-Socialist Romania: Labor, the Body, and WorkingClass Culture. Bloomington and Indianapolis: Indiana University Press.

Kočevar, Božo. n.d. "Kulturna dediščina avtomobilske industrije v Novem mestu". Rast: revija za kulturo, umetnost in družbena vprašanja. At http://kultura.novomesto.si/si/ revija-rast/?id=7093 (accessed 27 March 2013).

Linkon, Sherry Lee and John Russo. 2002. Steeltown U.S.A.: Work and Memoryin Youngstown. Lawrence: University Press of Kansas.

Marković, Predrag. 2002. "Sećanja na rad u jugoslovenskom socijalizmu između kritike i mita o Zemlji Dembeliji”. Godišnjak za društvenu istoriju 9/1-3: 51-67.

Matošević, Andrea. 2011. Pod zemljom: Antropologija rudarenja na Labinštini u XX. stoljeću. Zagreb: Institut za etnologiju i folkloristiku.

Muehlebach, Andrea. 2011. "The Museumization of Fordism". Unpublished paper, presented at the 18th International Conference of Europeanists, Barcelona, 20-22. June.

Muzej premogovništva Slovenije. At http://muzej.rlv.si/en/visit (accessed 18 January 2013).

"Muzej premogovništva Slovenije - predstavitev". At http://www.sloveniaholidays.com/ muzej-premogovnistva-slovenije-velenje.html (accessed 18 January 2013).

Nadkarni, Maya. 2007. “The Master's Voice: Authenticity, Nostalgia, and the Refusal of Irony in Postsocialist Hungary". Social Identities 13/5: 611-626.

Oder, Karla. 2012. "Mati fabrika - Železarna Ravne”. Historični seminar 10, Ljubljana: Založba ZRC, 13-45.

Palmberger, Monika. 2008. "Nostalgia Matters: Nostalgia for Yugoslavia as Potential Vision for a Better Future". Sociologija 50/4: 355-370.

Petrović, Tanja. 2010. "When We Were Europe: Socialist Workers in Serbia and Their Nostalgic Narratives." In Remembering Communism: Genres of Representation. Maria Todorova, ed. New York: Social Science Research Council, 127-153.

Petrović, Tanja. 2011. "The Political Dimension of Post-Socialist Memory Practices: SelfOrganized Choirs in the Former Yugoslavia". Südosteuropa 59/3: 315-329.

Petrović, Tanja. 2012. Yuropa: Jugoslovensko nasleđe $i$ politike budućnosti u postjugoslovenskim društvima. Beograd: Fabrika knjiga.

Potkonjak, Sanja and Tomislav Pletenac. 2011. "Kada spomenici ožive - 'umjetnost sjećanja' u javnom prostoru”. Studia ethnologica Croatica 23: 7-24.

"Poslanstvo muzeja”. Muzej premogovništva Slovenije. At http://muzej.rlv.si/si/o-nas/ poslanstvo-muzeja (accessed 18 January 2013).

Ramovš, Adela. 2010. “Cockta: Zgodba o pijači vaše in naše mladosti.” In Cockta: Pijača vaše in naše mladosti - o dediščini slovenskih blagovnih znamk. Adela Ramovš, ed. Ljubljana: Slovenski etnografski muzej, 55-88.

Robertson, Iain J. M. 2008. "Heritage from below: Class, Social Protest and Resistance". In Heritage and Identity, Brian Graham and Peter Howard, eds. Aldershot: Ashgate, 143-158. 
Rogelj Škafar, Bojana. 2010. "What do brands and the (Slovene Ethnographic) Museum have in common". In Cockta: Pijača vaše in naše mladosti - o dediščini slovenskih blagovnih znamk. Adela Ramovš, ed. Ljubljana: Slovenski etnografski muzej, 7-8.

Sayer, Andrew. 2005. The Moral Significance of Class. Cambridge: Cambridge University Press.

Schönle, Adreas. 2011. Architecture of Oblivion: Ruins and Historical Consciousness in Modern Russia. De Kalb: Northern Illinois University Press.

Scribner, Charity. 2002. "John Berger, Leslie Kaplan, and the Western Fixation on the 'Other Europe.'” In Inszenierung des kollektiven Gedächtnisses: Eigenbilder, Fremdbilder. Innsbruck et al.: Studien Verlag, 236-246.

Scribner, Charity. 2003. Requiem for Communism. Cambridge, MA and London: The MIT Press.

Shackel, Paul. 2009. An Archaeology of American Labor and Working Class Life. Gainesville: University of Florida Press.

Smith, Laurajanne. 2006. Uses of Heritage. London and New York: Routledge.

Smith, Laurajanne, Paul Shackel and Gary Campbell. 2011. "Introduction: Class Still Matters." In Heritage, Labor and the Working Classes, Laurajanne Smith, Paul Shackel and Gary Campbell, eds. New York: Routledge, 1-16.

Todorova, Maria and Zsuzsa Gille, eds. 2010. Post-Communist Nostalgia. New York and Oxford: Berghahn Books.

Velikonja, Mitja. 2009a. "Lost in Transition: Nostalgia for Socialism in Post-socialist Countries". East European Politics and Societies 23/4: 535-551.

Velikonja, Mitja. 2009b. Titostalgija: Študija nostalgije po Josipu Brozu. Ljubljana: Mirovni inštitut.

"Vlada oživljava industrijske centre". 2011. At http://www.b92.net/biz/vesti/srbija. php?yyyy $=2011 \& \mathrm{~mm}=06 \& d d=09 \&$ nav_id=517847B92.net (accessed 12 June 2011).

Watson, Sheila, ed. 2007. Museums and Their Communities. New York: Routledge.

Wright, Patrick. 1985. On Living in an Old Country: The National Past in Contemporary Britain. London: Verso.

Workers' living culture. At http://www.gornjesavskimuzej.si/?page_id=885\&lang=en (accessed 18 January 2013).

Wow, industry! At http://www.maribor2012.eu/en/nc/project/prikaz/116561/ (accessed 18 January 2013).

Zagrebačka industrijska baština. 2010. At http://www.zg-ib.org (accessed 31 January 2013).

"Zgodovina. Revoz". At http://www.revoz.si/sl/inside.cp2?cid=1A97EFE5-499D-F3705A19-8D9C5FB6A984\&linkid=inside (accessed 27 March 2013). 